\title{
Land Access and Household Food Security in Kpomassè District, Southern Benin: A Few Lessons for Smallholder Agriculture Interventions
}

\author{
Augustin K. N. Aoudji ${ }^{1,3}$, Prudence Kindozoun ${ }^{2}$, Anselme Adégbidi ${ }^{1} \&$ Jean C. Ganglo ${ }^{3}$ \\ ${ }^{1}$ School of Economics, Socio-Anthropology and Communication for the rural development, Faculty of \\ Agricultural Sciences, University of Abomey-Calavi, 03 BP 2819 Cotonou, Benin \\ ${ }^{2}$ Training and Research Unit of Agronomic Sciences, African University of Technology and Management, 04 BP \\ 1361 Cotonou, Benin \\ ${ }^{3}$ Laboratory of Forest Sciences, School of Environmental Management, Faculty of Agricultural Sciences, \\ University of Abomey-Calavi, 03 BP 2819 Cotonou, Benin \\ Correspondence: Augustin K. N. Aoudji, School of Economics, Socio-Anthropology and Communication for the \\ rural development, Faculty of Agricultural Sciences, University of Abomey-Calavi, 03 BP 2819 Cotonou, Benin, \\ Tel: 229-9748-1280. E-mail: augustin.aoudji@gmail.com or augustin.aoudji@ fsa.uac.bj
}

Received: August 6, 2017 Accepted: September 10, 2017 Online Published: September 23, 2017

doi:10.5539/sar.v6n4p104 URL: https://doi.org/10.5539/sar.v6n4p104

\begin{abstract}
Land remains a key asset in smallholder agriculture, and is expected to play a critical contribution to food security, still a major concern for decision makers. The objective of this study was to explore the relationship between land access mechanisms and the food security situation of households in Kpomassè district (southern Benin). A survey was conducted among 150 farmers selected randomly in six villages across the district. Data were collected on socio-demographic characteristics, access to land and food consumption patterns of the households. Data analysis encompassed a typology of households according to their access to land, by combining Hierarchical Cluster Analysis and Principal Component Analysis. The level of household food security was assessed by computing the food consumption score. Three types of producers were identified based on their access to land. These were typified as "renters", "borrowers" and "heirs", representing 44\%, 21\%, and $35 \%$ of the sample, respectively. The average food consumption score ranged between 51.9 and 57.4, showing a satisfactory food intake for all types of households. The study suggests that secure modes of access to land might improve the food security status of households through increased assets. Also, there is a need of capacity building for farmers, in order to address the critical issue of the impoverishment of soil, through fertility management programs. The issue of access to credit is also an important policy matter.
\end{abstract}

Keywords: farmland ownership, food consumption score, access to land, Kpomassè, southern Benin.

\section{Introduction}

Food security and poverty remain major challenges in the world, especially in Sub-Saharan Africa (Godfray et al., 2010; Garrity et al., 2010; Lobell et al., 2008). High performance agricultural systems are likely to play a significant role in food security in the region (Boussard, Daviron, Gerard, \& Voituriez, 2006; Food and Agriculture Organization of the United Nations [FAO], 2015; Sasson, 2012). The agricultural sector is the mainstay of Sub-Saharan Africa's economy. The importance this sector stems from its general role of food products provider, but also its importance in the livelihood of a majority of people across Sub-Saharan Africa. On average, agriculture contributes 15\% of total GDP in Sub-Saharan African region, and employs more than 50\% of the total work force (International Monetary Fund [IMF], 2012).

While agribusiness and commercial agriculture are being promoted across Sub-Saharan Africa, smallholder agriculture remains a key component of the region's policy agenda. This type of agriculture constitutes the overwhelming majority of farms in Sub-Saharan African, and employs almost all the agricultural workforce (Gollin, 2014). Therefore, smallholder agriculture is expected to make a critical contribution to food security in Sub-Saharan Africa (International Fund for Agricultural Development [IFAD], 2013; High Level Panel of Experts on Food Security and Nutrition [HLPE], 2013). 
Policies intended to improve agricultural efficiencies, should focus on smallholder farmers and their access to output markets and factors of production. Land is a key factor of production in smallholder agriculture, where the level of capital is often very low. Beyond its critical and primary role of factor of production, the land can be useful to farmers to have access to other resources such as financial services. Stated alternatively, land is a source of food security, social and cultural identity, and a key contributor to livelihoods. Therefore, an adequate policy of land resource management and efficient agricultural production is expected to have a positive effect on food security in Sub-Saharan Africa (Sanchez \& Leakey, 1997). Maxwell \& Wiebe (1999) demonstrated the linkage between land tenure and food security. However, there are few empirical evidences, especially in Sub-Saharan Africa where food security remains a major policy matter.

The objective of this study was to explore the relationship between land access mechanisms and the food security situation of households in Kpomassè district (southern Benin). In the southern region of Benin, land access generally appears as a critical issue for most farmers (Mongbo, 2000; Millenium Challenge Account [MCA]-Bénin, 2010). Besides, Kpomassè district is a rural area reported to be at food insecurity risk (World Food Programme [WFP], 2009). To engage policy makers in credible support to land access, it might be important to provide them with evidence of the potential returns from improved access to land among smallholder farmers. The assumption behind this study is that the alleviation of farmers' constraints for access to land can improve the food security status of their household.

This study built on an analytical framework linking the food security status to a typology of the farm households. The interest of a typology stems from the recognition of the diversity across farmers (Bidogeza, Berentsen, De Graaff, \& Oude Lansink, 2009; Gafsi, Dugué, Jamin, \& Brossier, 2007; McElwee \& Bosworth, 2010). The importance of developing a typology stems from the fact that it helps to develop specific policy interventions, for specific groups of farmers, hence improved effectiveness and efficiency of development interventions (Gafsi et al., 2007). This approach is suited to explore socio-economic issues related to the food security status of farmers. Even though this study took place in southern Benin, it is useful to enlighten decision makers across Sub-Saharan Africa, given the importance of food security issue across the continent, and the challenge of the sustainable management of the continent's land resource, for the fair access to all people.

This article progresses as follows. The research methods are developed in the next section. Results appear in section 3, and discussions of the results are presented in section 4. In the last section, the main findings are summarized with the related policy implications.

\section{Material and Methods}

\subsection{Data Collection}

A survey was carried out in Kpomassè district (Figure 1) located in the Atlantique department (southern Benin) from November 2014 through January 2015. Data collection followed two stages: the exploratory survey and the in-depth survey. The exploratory survey was based on semi-structured interviews and focus group discussions, in order to get a general understanding of the mechanisms of access to land in Kpomassè, and conduct a pre-test of the questionnaire used in the next stage.

During the in-depth survey, data were collected based on face-to-face interviews with a standardized questionnaire. The sample included 150 households selected randomly in six villages across the district (Figure 1). Respondents were household heads, but when needed, they were assisted by other family members to ensure the consistency of all responses. Besides households' socio-demographic characteristics, the questionnaires encompassed two main items: the access to land and food consumption patterns of the household.

About access to land, an inventory of all plots of the household was done, including lands in fallow. The acreage of each plot was recorded, with the type of farmland ownership. Respondents were also asked to talk about the constraints encountered in land access. At this point, they were asked to rank by order of importance five constraints selected from the exploratory survey.

To assess household's level of food security, the WFP's (2009) approach based on the Food Consumption Score was used. The number of consumption days in one week was recorded for various food categories, namely cereals, roots and tubers, leguminous, vegetables, fruits, animal protein, milk products, sugar, oil, and seasoning. 


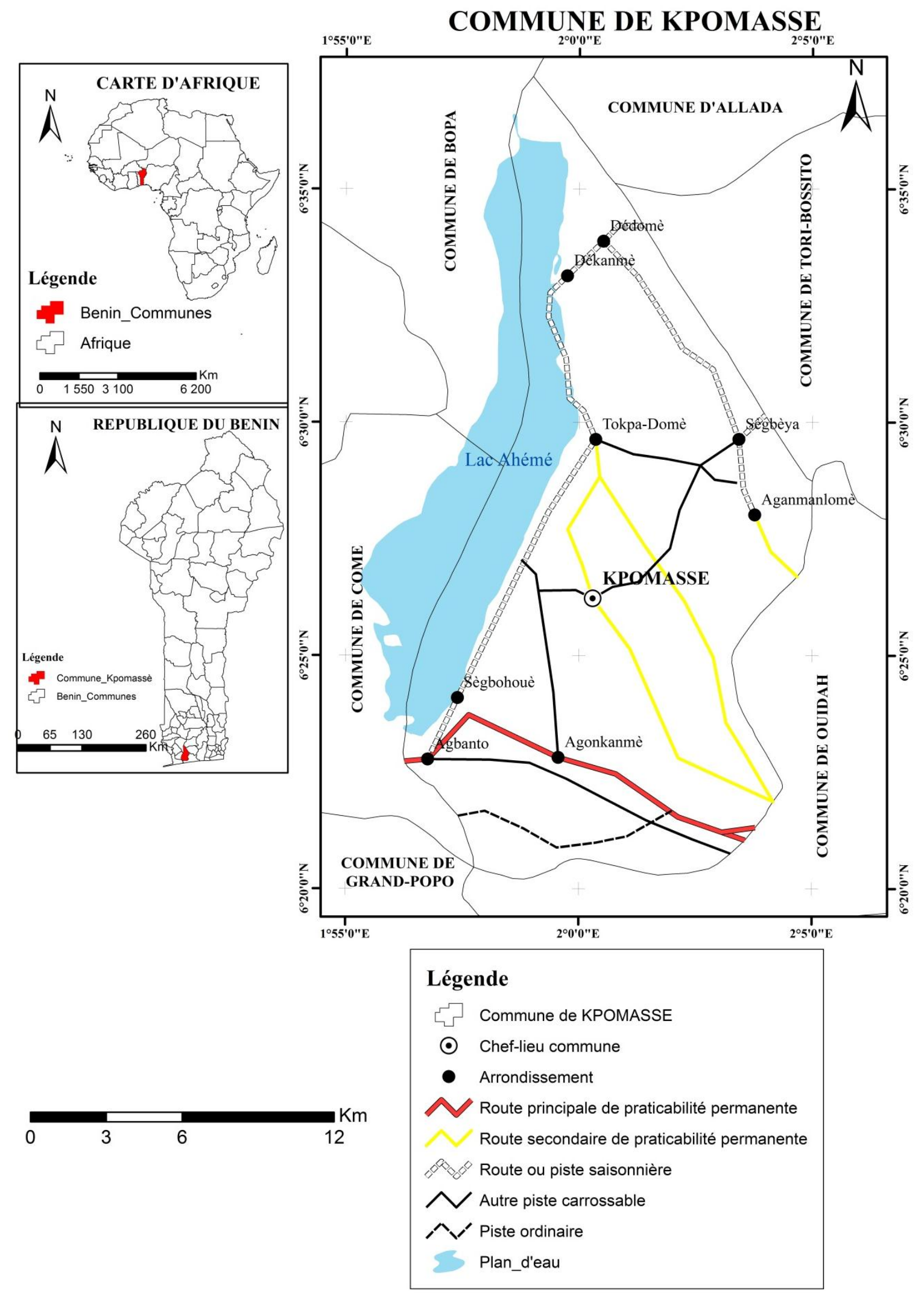

Figure 1. Map of Kpomassè district in southern Benin 


\subsection{Data Processing and Analysis}

Data processing included the characterization of the sample based on key socio-demographic variables. This was followed by the topology of households according to land access, and the analysis of household food security situation.

\subsubsection{Household Typology According To Land Access and Their Constraints}

The typology of households according to land access was done by performing a hierarchical ascending cluster analysis. "Cluster analysis provides a multivariate technique specifically suited to the development of a typology" (Moos \& Moos, 1976). Squared Euclidean distance was used as similarity measure, and agglomeration was based on Ward's method (Batagelj, 1988; Glèlè-Kakaï \& Kokodé, 2004). The classificatory variables used in this analysis were the farm size, and the proportion of the various types of farmland ownership encountered in the total acreage (inheritance, purchase, renting, loan, and sharecropping). All the classificatory variables were standardized. Principal Components Analysis was performed to interpret clusters' characteristics (Glèlè-Kakaï \& Kokodé, 2004). Farmers' socio-demographic profile was described across clusters, by using the following variables: gender, age, household size, and number of laborers.

The ranking of the constraints to land access was done by type of household previously identified. The calculation of the mean ranks enabled to classify the constraints by decreasing order of importance. The level of agreement among respondents over the ranking was assessed by performing Kendall's test of concordance (Lewis \& Johnson, 1971).

\subsubsection{Assessment of Households' Level of Food Security}

The first stage was the determination of the food consumption score (FCS), a proxy indicator showing the diversity, the frequency, and the nutritional intake of food products consumed by households (WFP, 2009). The FCS is calculated based on the consumption frequency of eight different categories of foods (Brown, 2012):

$$
F C S=a_{\text {cereal }} X_{\text {cereal }}+a_{\text {leguminous }} X_{\text {leguminous }}+a_{\text {vegetable }} X_{\text {vegetable }}+a_{\text {fruit }} X_{\text {fruit }}+a_{\text {animal }} X_{\text {animal }}+a_{\text {sugar }} X_{\text {sugar }}+a_{\text {milk }} X_{\text {milk }}+a_{\text {oil }} X_{\text {oil }}
$$

With $X_{i}$, the number of consumption days for each category of food ( $\leq 7$ days); $a_{i}$, the score related to food categories (Table 1).

Table 1. Score of various food categories in the calculation of the FCS

\begin{tabular}{llc}
\hline Categories of foods & Types of foods & Score \\
\hline Cereals and tubers & Maize, millet, sorghum, rice, breads/cakes, & 2 \\
& food pasts, cassava, yam, plantain, other tubers & \\
Leguminous & Groundnuts, bean, cowpea, pea, lentils, etc. & 3 \\
Vegetables & Vegetables (+ leaves) & 1 \\
Fruits & Fruits (mangoes, oranges, bananas, etc.) & 1 \\
Animal proteins & Meats, fishes, sea fruits, snails, eggs & 4 \\
Milk products & Milk, milk products & 4 \\
Sugars & Sugar, honey, other sweet foods & 0.5 \\
Oils & Oil and fats & 0.5 \\
\hline
\end{tabular}

Source: WFP (2009)

The mean food security score of the whole sample was compared to the reference value of 35 by performing Student's $t$ test of conformity (Glèlè-Kakaï \& Kokodé, 2004). FCS $>35$ corresponds to an acceptable level of food consumption (Brown, 2012). One-way analysis of variance (ANOVA) was performed to test for the variation of FSC across the categories of households.

\section{Results}

\subsection{Socio-demographic Characteristics of the Sample}

The main socio-demographic characteristics of the surveyed farm households are summarized in table 2. 
Table 2. Socio-demographic characteristics of surveyed farm households

\begin{tabular}{llc}
\hline Characteristics & & Value \\
\hline \multirow{2}{*}{ Gender (\%) } & Male & 76.7 \\
& Female & 23.3 \\
\hline Age (years) & Mean \pm Standard deviation & $44.8 \pm 14.0$ \\
\hline Marital status (\%) & Single & 0.7 \\
& Married & 90 \\
& Widowed & 5.3 \\
& Divorced & 4 \\
\hline Household size & Mean & 6.56 \\
\hline Education level (\%) & No schooling & 44.7 \\
& Primary school & 35.3 \\
& Secondary school & 19.3 \\
& University & 0.7 \\
\hline Main activity (\%) & Agriculture & 98.0 \\
& Crafting & 0.7 \\
& Liberal profession & 0.7 \\
& Fishing & 0.7 \\
\hline & None & 53.4 \\
& Agriculture & 3.3 \\
& Trade & 13.3 \\
Secondary activities (\%) & Crafting & 6.7 \\
& Employees & 1.3 \\
& Liberal profession & 22.0 \\
\hline
\end{tabular}

The sample was dominated by men-led households; female-headed households represented less than one quarter of the sample (Table 2). Respondents' age ranged between 20 and 80 years old, and averaged 45 years. The marital status was characterized by the predominance of married people who represented nine tenth of the respondents (Table 2). The sample also included a small proportion of widowed, divorced, and singles (Table 2).

Regarding education level, more than two fifth of the sample were illiterate; about one third had a formal education at primary level; and about one fifth received a formal education at secondary school level. A minority of people (less than $1 \%$ ) had a university degree (Table 2).

Farming was by far households' main activity, with nine tenth of the sample (Table 2). However, a small proportion of people were engaged in agriculture as a secondary activity. The other professions encountered (principal or secondary activity) included crafting, trade, employee, and liberal profession.

Regarding the organization of farming activities, two types of family labor were used. These included permanent laborers (about 1.2 persons per household) and temporary laborers (about 1.6 persons per household).

\subsection{Farmland Ownership}

There was a wide variability in the size of land exploited (Table 3). This ranged between 0.32 ha and 28 ha, and averaged 4.1 ha. $50 \%$ of households exploited less than 2.72 ha, and $75 \%$ of them exploited more than 4.5 ha (Table 4).

Table 3. Distribution of the size of farmland exploited by households

\begin{tabular}{lc}
\hline Parameter & Value (ha) \\
\hline Minimum & 0.32 \\
First quartile & 1.6 \\
Second quartile & 2.72 \\
Third quartile & 4.50 \\
Maximum & 28.0 \\
Mean & 4.1 \\
\hline
\end{tabular}

Land inheritance was the dominant farmland ownership, with more than two thirds of the total farm acreage of households (Figure 2). This was followed by renting, about one third of the sample (Figure 2). Sharecropping 
and loan represented about one tenth of the farmland while land purchase was rare, about $5 \%$ of farmland ownership in the sample (Figure 2).

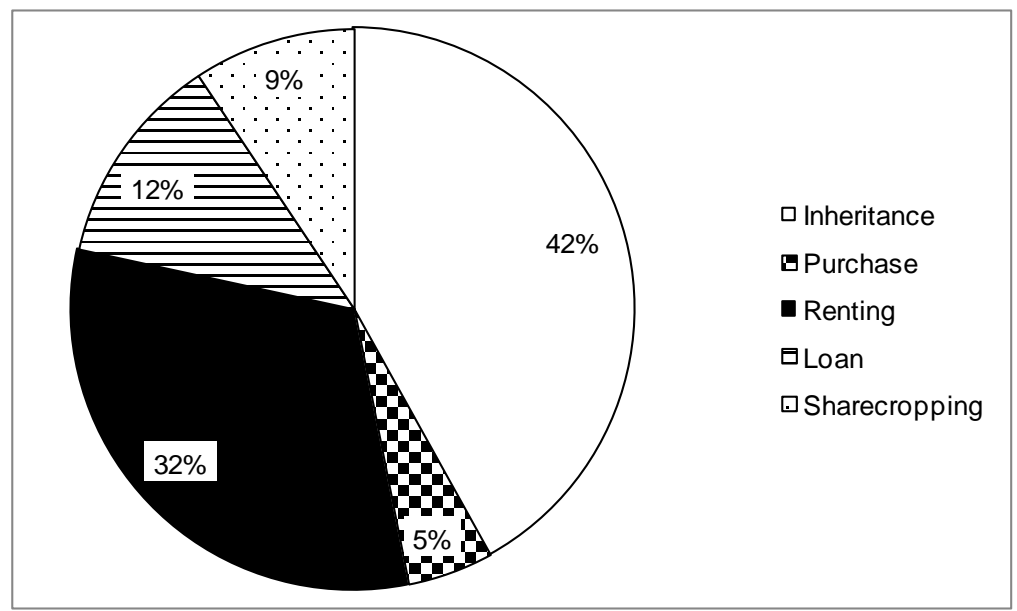

Figure 2. Proportion of land ownership types in the sample

\subsection{Typology of Household for Land Access}

\subsubsection{Differentiation of Land Access Mechanisms}

Three farmer clusters were identified based on the dendrogram of the hierarchical ascending cluster analysis (Figure 3). Each farmer group is related to a particular mode of land access.

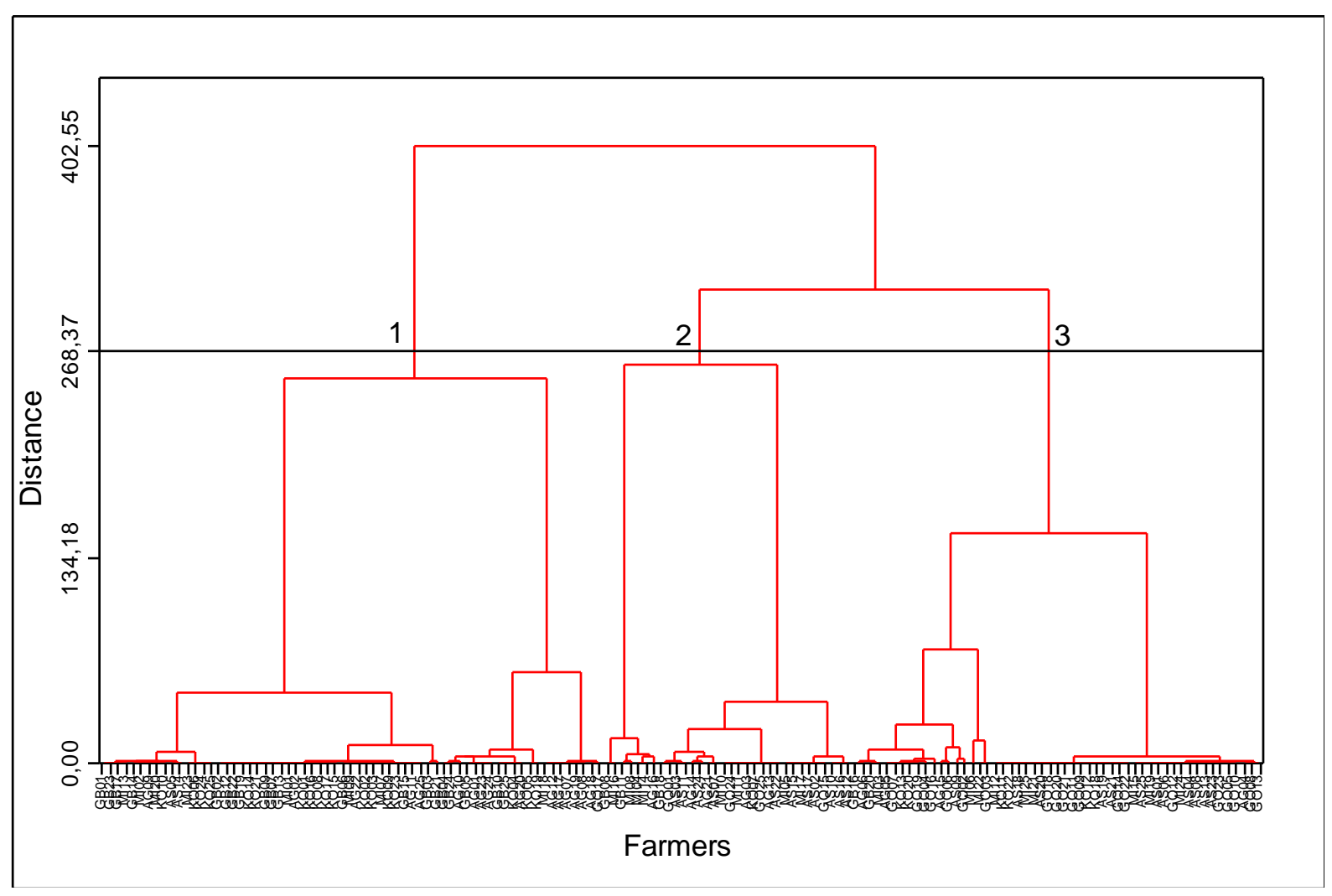

Figure 3. Dendrogram of the hierarchical ascending cluster analysis showing household typology according to land access

The interpretation of the Principal Component Analysis was based on the first two components which explained 
$48 \%$ of the variability (Table 4). The correlation between principal components (PC) and the original variables (Table 5) showed that Component 1 had a high and negative correlation with land inheritance, and a high and positive correlation with land renting. On the other side, Component 2 showed a high and positive correlation with land loan (table 5).

Table 4. Eigen analysis of the correlation matrix

\begin{tabular}{lcccccc}
\hline & PC1 & PC2 & PC3 & PC4 & PC5 & PC6 \\
\hline Eigenvalue & 1.6697 & 1.2285 & 1.1804 & 1.0615 & 0.8599 & -0.0000 \\
Proportion & 0.278 & 0.205 & 0.197 & 0.177 & 0.143 & -0.000 \\
Cumulative & 0.278 & 0.483 & 0.680 & 0.857 & 1.000 & 1.000 \\
\hline
\end{tabular}

PC: Principal component

Table 5. Correlation between original variables and principal components (PC)

\begin{tabular}{lllllll}
\hline Variable & PC1 & PC2 & PC3 & PC4 & PC5 & PC6 \\
\hline Total farm acreage & -0.270 & -0.119 & -0.457 & -0.210 & -0.812 & 0.000 \\
Inheritance & -0.699 & -0.311 & 0.178 & 0.082 & 0.157 & -0.593 \\
Purchase & -0.004 & 0.229 & -0.343 & -0.801 & 0.368 & -0.232 \\
Renting & 0.607 & -0.439 & -0.317 & 0.167 & -0.002 & -0.557 \\
Loan & -0.037 & 0.782 & -0.236 & 0.406 & -0.074 & -0.400 \\
Sharecropping & 0.262 & 0.179 & 0.697 & -0.338 & -0.418 & -0.352 \\
\hline
\end{tabular}

PC: Principal component

The interpretation of the factorial plan 1/2 of the PCA (Figure 4) was done based on the correlations between the principal components and the original variables (Table 5). The members of cluster 1 are located in the positive side of Component 1 . Therefore, this cluster was characterized by a high proportion of rented lands, and a low proportion of inherited lands. Farmers of cluster 2 are located in the positive size of component 2 so that they are characterized by a high proportion of borrowed land (loan). Regarding the farmers of cluster 3 , they are located in the negative side of component 1 . Therefore, this cluster is characterized by a high proportion of inherited lands and a low proportion of rented lands.

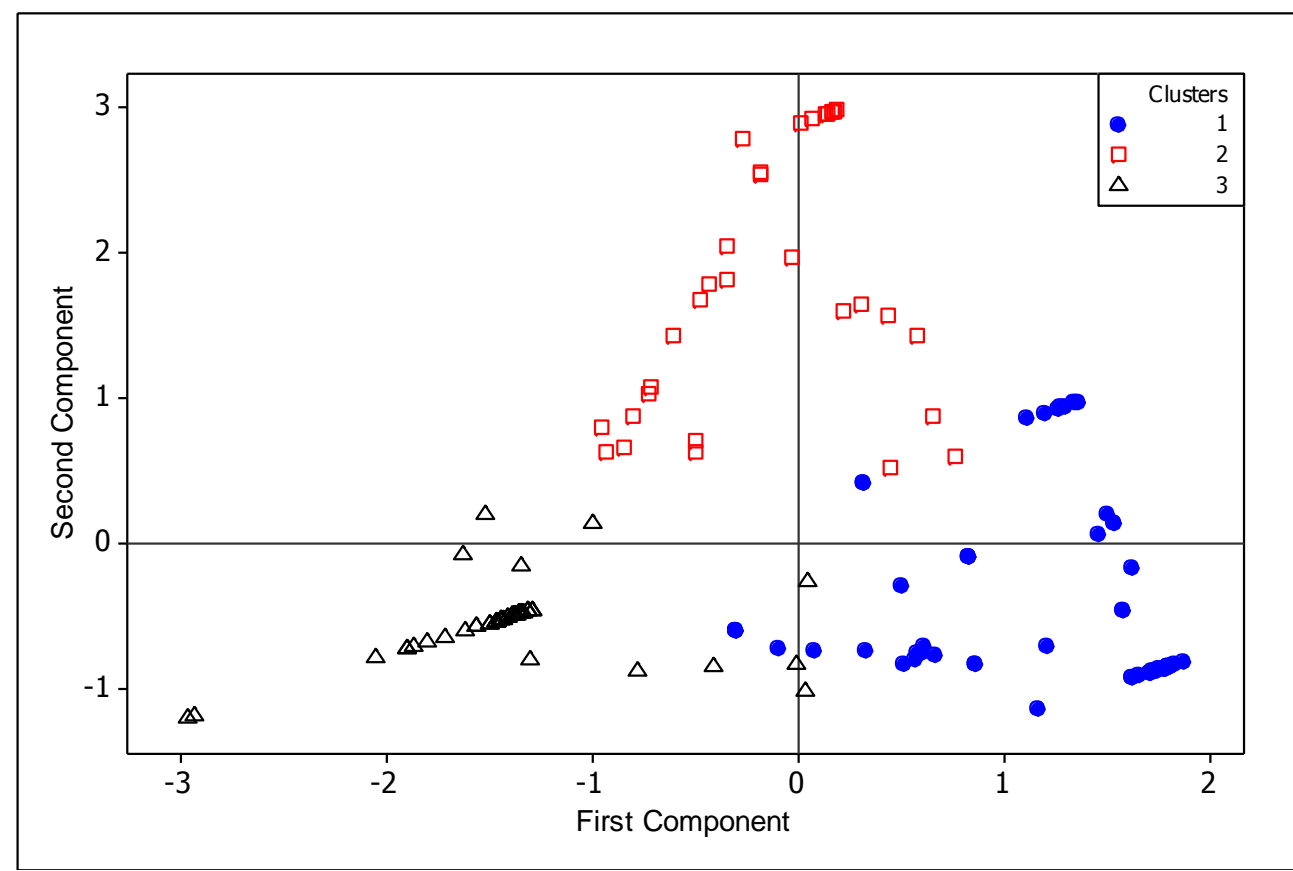

Figure 4. Score plot for components 1 and 2 from PCA

Clusters from the hierarchical ascending classification are shown as dots (cluster 1), squares (cluster 2), and triangles (cluster 3). 


\subsubsection{Characteristics of Farmer Clusters}

Table 6 illustrates the characteristics of the various types of farmers according to clustering variables.

Table 6. Characteristics of the types of household according to land access

\begin{tabular}{|c|c|c|c|c|c|c|}
\hline \multirow{2}{*}{$\begin{array}{l}\text { Types of } \\
\text { farmers }\end{array}$} & \multirow{2}{*}{$\begin{array}{l}\text { Farm acreage } \\
\text { (ha) }\end{array}$} & \multicolumn{5}{|c|}{ Proportion of farmland ownerships } \\
\hline & & $\begin{array}{c}\text { Inheritance } \\
(\%)\end{array}$ & $\begin{array}{c}\text { Purchase } \\
(\%)\end{array}$ & $\begin{array}{c}\text { Renting } \\
(\%)\end{array}$ & $\begin{array}{c}\text { Loan } \\
(\%)\end{array}$ & $\begin{array}{c}\text { Sharecropping } \\
(\%)\end{array}$ \\
\hline Cluster 1 & 2.7 & 13.1 & 0.2 & 65.6 & 0.0 & 21.2 \\
\hline Cluster 2 & 3.7 & 18.9 & 18.1 & 5.7 & 56.4 & 0.9 \\
\hline Cluster 3 & 6.0 & 91.3 & 2.8 & 5.4 & 0.5 & 0.0 \\
\hline
\end{tabular}

Cluster 1 was dominated by small farmers exploiting the smallest farmland. Renting was the main type of farmland ownership (about $2 / 3$ of the total farmland). Sharecropping was the second most important type of farmland ownership in this cluster, with more than $1 / 5$ of the total farmland. This was followed by inheritance which proportion exceeded on average 1/10 of the total exploited farmland. Overall, cluster 1 was characterized by the wide predominance of indirect farmland ownership (renting, loan, and sharecropping) which represented $86.8 \%$ of the total farmland (Table 6).

Cluster 2 was characterized by intermediate farm size, compared to the two other clusters. The dominant farmland ownership in this cluster was the loan which represented more than half of the total farmland (Table 6). Direct farmland ownership (inheritance and purchase) represented 37\% of the total farmland (Table 6).

Cluster 3 was characterized by a relatively large farmland, compared to the two other clusters. The overwhelming majority of their farmland (more than 9/10) was got from inheritance (Table 6). In this cluster, a small acreage was exploited as indirect farmland ownership (renting, loan, and sharecropping): $5.9 \%$ of the total farmland (Table 6).

Given their respective characteristics presented above, clusters 1,2, and 3 have been typified, and will be further referred to as renters, borrowers, and heirs, respectively. These various types of households were represented unequally in the sample (Figure 5). Renters were the most represented category (more than 2/5). They were followed by heirs with a proportion exceeding slightly one third. Last, the borrowers were the less represented in the sample, with a proportion of about $1 / 5$.

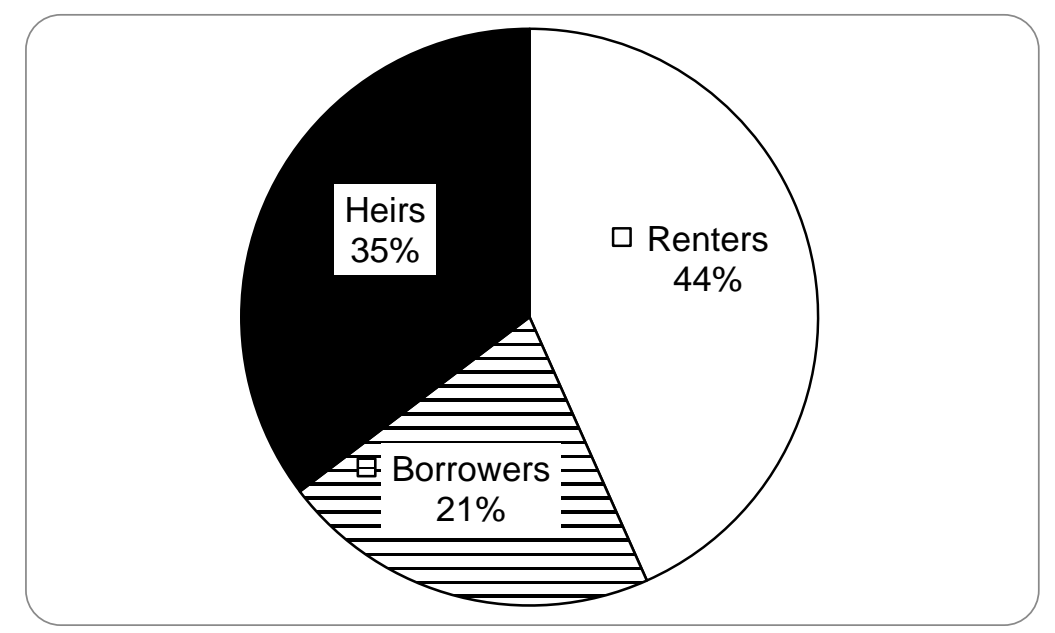

Figure 5. Representativeness of the various land access modes in the sample

\subsubsection{Characterization of the Types of Farmers According to Land Access Modes}

Despite various land access modes, the three categories of households showed similarities in their socio-demographic characteristics (Table 7). Age was the only variable showing significant differences across the identified clusters. The average age of borrowers was significantly higher, compared to the two other categories. Regarding gender, the proportion of men-led households was higher in all clusters. However, the proportion of women was relatively lower in the cluster of heirs, compared to the two other clusters, but these differences were not significant. Household size and the number of laborers did not show consistent differences 
across households types (Table 7).

Tableau 7. Main socio-demographic characteristics across types of farmers

\begin{tabular}{lccc}
\hline Characteristics & \multicolumn{3}{c}{ Type of farmer } \\
\cline { 2 - 4 } & Renters & Borrowers & Heirs \\
\hline Gender & & & \\
Male (\%) & 73.8 & 75.0 & 81.1 \\
Female (\%) & 26.2 & 25.0 & 18.9 \\
Age* (years) & $42.2 \mathrm{a}$ & $49.4 \mathrm{~b}$ & $45.3 \mathrm{a}$ \\
Household size & 6.8 & 7.0 & 6.1 \\
Number of laborers & 1.8 & 2.1 & 2.8 \\
\hline
\end{tabular}

*Variable showing significant differences across clusters. Means significantly different are followed by different letters.

\subsubsection{Constraints to Land Access}

Five major constraints to land access were pointed out by farmers, namely impoverishment of soils and infestation by Imperata cylindrica, scarceness of cultivated land, high renting fees, lack of credit facilities, and land conflict. The ranking of these constraints differed slightly across the clusters (Table 8). The major constraints were impoverishment of soils and infestation by Imperata cylindrica, the high renting fees, and lack of credit facilities, respectively for the renters, the borrowers, and the heirs. The scarceness of cultivated lands ranked second among the constraints, whichever the cluster considered (Table 8). Overall, land conflict did not seem to be an impediment to land access, insofar as this was ranked in all clusters as the less important constraint to land access (Table 8).

Table 8. Ranking of constraints to land access across types of farmers

\begin{tabular}{lccc}
\hline \multirow{2}{*}{ Constraints } & \multicolumn{3}{c}{ Types of farmers } \\
\cline { 2 - 4 } & Renters & Borrowers & Heirs \\
\hline Impoverished land /Imperata cylindrica & $1(2.06)$ & $4(2.72)$ & $3(2.70)$ \\
Scarceness of cultivable lands & $2(2.18)$ & $2(2.41)$ & $2(2.43)$ \\
High renting fees & $3(2.35)$ & $1(2.34)$ & $4(2.89)$ \\
Lack of credit facilities & $4(3.42)$ & $3(2.53)$ & $1(2.13)$ \\
Land conflicts & $5(4.98)$ & $5(5.00)$ & $5(4.85)$ \\
\hline
\end{tabular}

*Bracketed figures represent the average rankings.

Kendall's test of concordance (Table 9) showed a satisfactory level of agreements among farmers regarding the ranking of constraints to land access, whichever the cluster considered (all $\mathrm{p}<0.05$ ). However, the level of agreement was relatively higher among the clusters of renters and borrowers (Kendall's coefficient of concordance superior to 0.5), compared to the cluster of heirs where the Kendall's coefficient of concordance was lower than 0.5 (Table 9).

Table 9. Results of Kendall's test of concordance

\begin{tabular}{lccc}
\hline Parameters & \multicolumn{3}{c}{ Type of farmer } \\
\cline { 2 - 4 } & Renters & Borrowers & Heirs \\
\hline $\mathrm{N}$ & 65 & 32 & 53 \\
Kendall's W & 0.607 & 0.508 & 0.460 \\
Chi-Square & 157.932 & 65.050 & 97.449 \\
Df & 4 & 4 & 4 \\
Asymp. Sig. & 0.000 & 0.000 & 0.000 \\
\hline
\end{tabular}

a: Kendall's Coefficient of Concordance

\subsection{Household Food Security}

Household food consumption score ranged between 26 and 79, and averaged 54.18 for the whole sample. This average score was significantly higher than the reference value of 35 , signifying a satisfactory level of food consumption (Student's $t$ test; $t=27.747 ; \mathrm{p}<0.01$ ). This result showed that, overall, the surveyed households 
enjoyed a satisfactory level of food security.

Household food consumption score varied according to land access modes (ANOVA; $\mathrm{F}=6.714 ; \mathrm{p}<0.01$ ). The group of heirs had a higher level of food security (higher food consumption score), compared to the two other categories of farmers (Table 10).

Table 10. Food Consumption Score across the various categories of households

\begin{tabular}{lc}
\hline Modes of access to land & Mean FCS \\
\hline Renters & $51.9 \mathrm{a}$ \\
Borrowers & $53.5 \mathrm{a}$ \\
Heirs & $57.4 \mathrm{~b}$ \\
\hline
\end{tabular}

*Figures followed by the same letter are not significantly different (ANOVA; $p<5 \%$ ).

\section{Discussion}

\subsection{Land Ownership and Typology of Farmers According to Land Access}

This study revealed that the dominant modes of access to land in the locality were renting, loan, and inheritance. This is consistent with the three categories of farmers identified. Loan and renting (65\% of land access modes) are helpful to farmers who lack resources to buy lands. However, the predominance of these indirect modes of access to land means potential risks of conflicts and land insecurity for the majority of producers. In fact, it is known that indirect modes of access to land lead to increased risks of land insecurity, compared to direct modes of access to land in Benin (MCA-Bénin, 2010).

The category of renters had the lowest farm size ( 2.7 ha on average), though no significance difference was found with the borrowers ( 3.7 ha on average). The smaller area grown by renters stems from the relatively high renting fees, given the local context of the region. In the study period, the renting cost of land in Kpomassè region was XOF 120,000-180,000 (USD 240-360) per hectare per year. Regarding loan, there is no financial cost associated to this mode of access to land. The lands obtained that way often belong to relatives established in cities. The loan brings mutual advantages to both parties: it helps the user to have access to land for agricultural production; and it helps the landholder to keep his plot safe.

The relatively high land acreage in the category of heirs (35\% of farmers) stems from the fact that this group is composed of descendants of autochthon landholders. However, this mode of access to land could result over time in land fragmentation, i.e. the significant reduction of the size of agricultural lands; given that repetitive sharing will result in smaller and smaller land plots for younger generations. Land fragmentation can affect the overall efficiency of agricultural production. Evidence of the detrimental effect of land fragmentation on the efficiency of farmers has been reported in other regions (Niroula \& Thapa, 2005; Rahman \& Rahman, 2009; Tan, Heerink, Kuyvenhoven, \& Qu, 2005).

Among the land access modes, sharecropping ( $0-21 \%$ of households across the types of farmers) and purchase (0.2-18\% of households across the various categories) were less represented (Table 6). The low proportion of purchased lands could stem from the limited development of land market, and the lack of financial resources by most farm households to engage in land transactions. This highlights the constraint of access to credit which is often viewed as an impediment is smallholder agriculture (Swinnen, Colen, \& Maertens, 2013; McIntosh, Sarris, \& Papadopoulos, 2013). Regarding sharecropping, its low representativeness could stem from the preference of landholders for cash transactions, i.e. renting, because the quantity of produce received by landholders might vary because of factors such as climate variability. Also, most land seekers are reluctant to engage in sharecropping.

The characterization of the various types of farm households showed significant difference for the age of household heads. The higher age of borrowers (Table 7) might mean that oldness is a criterion to deserve confidence toward the landholders.

Regarding gender, although the difference was not significant, women were less represented in the category of heirs. Though the law gives the same right to men and women for inheritance, this is not respected in practice; so that women are often excluded from land inheritance sharing.

\subsection{Constraints to Land Access}

Land access constraints were ranked differently across clusters. For renters, the key constraint was the 
impoverishment of land, and infestation by weeds. In fact, impoverished lands are less attractive for agricultural production because of their low productivity. Field observation showed a trend of Imperata cylindrica to develop on degraded lands. The issue of Imperata cylindrica is critical because of effects such as reduction of crop yield and quality, injury to the skin, and increased labor requirement (Chikoye, Manyong, \& Ekeleme, 2000). Previous studies have identified weed as a constraint to farmers (Vissoh, Gbèhounou, Ahanchédé, Kuyper, \& Röling, 2004; Rodenburg \& Johnson, 2009). The constraints of land impoverishment and infestation suggest the need of programs of sustainable management of soil fertility. In fact, the impoverishment of land might stem from poor practices of fertility management.

Regarding the borrowers, their main constraint was the high cost of land renting or purchase in the region, so that they have to cope with land borrowing. Lastly, heirs considered that limited opportunity of credit is the major constraint to access to land. The rationale is that the lack of credit opportunity does not enable them to increase their farmland, and strengthen their production system. This study confirms the need of financial service in any strategy of rural development (Karlan, Osei, Osei-Akoto, \& Udry, 2014; Kassie, Teklewold, Jaleta, Marenya, \& Erenstein, 2015).

Farmers ranked land conflict as a low constraint to land access in Kpomassè district. This stems from the fact that land transactions were not developed in the region (Only 5\% of lands were purchased). In other regions of Benin, land transactions were the main sources of conflicts around agricultural lands (MCA-Bénin, 2010).

\subsection{Household Food Security and Relation to Modes of Land Access}

The use of the Food Consumption Score, a proxy indicator of food security showed that, overall, the households enjoyed a satisfactory level of food security. This result is surprising given that previous report by WFP (2009) typified Kpomassè district as vulnerable to food insecurity in Benin. As explanation, the efforts of Benin's government since the 2008 food crisis might have positively influenced the region's food security situation.

There was a relationship between land access and household food security. Heirs had a FCS significantly higher than for renters and borrowers. In fact, heirs had lager and more secure access to land (direct access), compared to the two other categories (renters and heirs). For example, they can grow perennial crops, contrary to the two other categories. The existence of perennial crops in their system of production means a diversification of sources of income, and a better ability to meet their needs of food consumption, especially in off-season. This analysis is consistent with the sustainable livelihoods approach (Chambers \& Conway, 1991), according to which rural communities depend on their access to natural capital, including the land.

\section{Conclusion}

The focal target of this study was to explore the relationship between land access mechanisms and the food security situation of farm households in Kpomassè district (southern Benin). Farmers had access to land through the following modes: inheritance, purchase, renting, loan, and sharecropping. Inheritance was the dominant mode of access to land across farm households. The typology resulted in three categories of farmers - typified as heirs, renters, and borrowers respectively - according to their access to land. The main impediments to land access were as follows: land impoverishment and infestation by weeds (Imperata cylindrica), the scarceness of cultivable lands, the high renting fees, and the lack of credit facilities.

The analysis of food consumption scores (FCS) showed a satisfactory level of food intake for all types of households. However, the food consumption scores varied consistently according to the categories of farmers, heirs having a higher value of FCS, compared to the two other clusters (renters and borrowers). The study suggests that secure modes of access to land might improve the food security status of households through increased assets. There is a need of capacity building for farmers to address the constraint of soil impoverishment and weed infestation, through soil fertility management programs. The issue of access to credit is also an important policy matter, but this is not a single pattern of farmers in Kpomassè district.

\section{References}

Batagelj, V. (1988). Generalized Ward and related clustering problems, in: Bock, H.H. (Ed.), Classification and related methods of data analysis, North-Holland, Amsterdam, 67-74.

Bidogeza, J. C., Berentsen, P. B. M., De Graaff, J., \& Oude Lansink, A. G. J. M. (2009). A typology of farm households for the Umutara Province in Rwanda. Food Security, 1(3), 321-335. https://doi.org/10.1007/s12571-009-0029-8

Boussard, J-M., Daviron, B., Gérard, F., \& Voituriez, T. (2006). Food security and agricultural development in Sub-Saharan Africa: Building a case for more public support. Working paper No. 01/E. 90p. 
http://www.fao.org/3/a-a0788e.pdf (Accessed 31 October 2016).

Brown, L. (2012). Food Consumption Score Overview. 6p.

Chambers, R., \& Conway, G. R. (1991). Sustainable Rural Livelihoods: Practical Concepts for the $21^{\text {st }}$ Century. Institute of Development Studies. Discussion Paper No 296, 1991. University of Sussex: Brighton.

Chikoye, D., Manyong, V. M., \& Ekeleme, F. (2000). Characteristics of speargrass (Imperata cylindrica) dominated fields in West Africa: crops, soil properties, farmer perceptions and management strategies. Crop Protection, 19(7), 481-487. https://doi.org/10.1016/S0261-2194(00)00044-2

FAO (2015). Regional overview of food insecurity: African food security prospects brighter than ever. Accra, FAO. http://www.fao.org/3/a-i4635e.pdf (Accessed 31 October 2016).

Gafsi, M., Dugué, P., Jamin, J.-Y., \& Brossier, J. (2007). Exploitations agricoles familiales en Afrique de l'Ouest et $d u$ Centre. Versailles, coéditions Quae - CTA.

Garrity, D. P., Akinnifesi, F. K., Ajayi, O. C., Weldesemayat, S. G., Mowo, J. G., Kalinganire, A., ... \& Bayala, J. (2010). Evergreen Agriculture: a robust approach to sustainable food security in Africa. Food Security, 2(3), 197-214. https://doi.org/10.1007/s12571-010-0070-7

Glèlè-Kakaï, R., \& Kokodé, G. G. (2004). Techniques statistiques univariées et multivariées : applications sur ordinateur. Note technique de biométrie, INRAB, Cotonou, Bénin.

Godfray, H. C. J., Beddington, J. R., Crute, I. R., Haddad, L., Lawrence, D., Muir, J. F., ... \& Toulmin, C. (2010). Food Security: The Challenge of Feeding 9 Billion People. Science, 327(5967), 812-818. https://doi.org/10.1126/science.1185383

Gollin, D. (2014). Smallholder agriculture in Africa: An overview and implications for policy, IIED Working Paper. IIED, London. https://pdfs.semanticscholar.org/6db6/1d7b6434f94fcdd733470d1a4d5e103ab8e1.pdf (Accessed 25 January 2017).

HLPE. (2013). Investing in smallholder agriculture for food security. A report by the High Level Panel of Experts on Food Security and Nutrition of the Committee on World Food Security, Rome.

IFAD (2013). Smallholders, food security, and the environment. http://www.unep.org/pdf/SmallholderReport_WEB.pdf (Accessed 23 January 2017).

IMF (International Monetary Fund) (2012). International Jobs Report, Economist Intelligence Unit, Washington, DC.

Karlan, D., Osei, R., Osei-Akoto, I., \& Udry, C. (2014). Agricultural Decisions after Relaxing Credit and Risk Constraints. The Quarterly Journal of Economics, 129(2), 597-652. https://doi.org/10.3386/w18463

Kassie, M., Teklewold, H., Jaleta, M., Marenya, P., \& Erenstein, O. (2015). Understanding the adoption of a portfolio of sustainable intensification practices in eastern and southern Africa. Land Use Policy, 42, 400-411. https://doi.org/10.1016/j.landusepol.2014.08.016

Lewis, G. H., \& Johnson, R. G. (1971). Kendall's Coefficient of Concordance for Sociometric Rankings with Self Excluded. Sociometry, 34(4), 496-503. https://doi.org/10.2307/2786195

Lobell, D. B., Burke, M. B., Tebaldi, C., Mastrandrea, M. D., Falcon, W. P., \& Naylor, R. L. (2008). Prioritizing Climate Change Adaptation Needs for Food Security in 2030. Science, 319(5863), 607-610. https://doi.org/10.1126/science.1152339

Maxwell, D., \& Wiebe, K. (1999). Land tenure and food security: exploring dynamic linkages. Development and Change, 30(4), 825-849. https://doi.org/10.1111/1467-7660.00139

MCA-Bénin (2010). Livre Blanc de Politique Foncière du Bénin (PROJET). 113p.

McElwee, G., \& Bosworth, G. (2010). Exploring the Strategic Skills of Farmers Across a Typology of Farm Diversification Approaches. Journal of Farm Management, 13(12), 819-838.

McIntosh, C., Sarris, A., \& Papadopoulos, F. (2013). Productivity, credit, risk, and the demand for weather index insurance in smallholder agriculture in Ethiopia. Agricultural Economics, 44(4-5), 399-417. https://doi.org/10.1111/agec.12024

Mongbo, R. L. (2000). Disponibilité en terres et régime foncier en milieu rural au sud Bénin, in: Lavigne Delville, P., Toulmin, \& C., Traoré, S. (Eds.), Gérer le foncier rural en Afrique de l'Ouest - Dynamiques locales et interventions publiques. Karthala-URED-Ministère des Affaires Étrangères, Paris, Saint-Louis, pp. 
185-204.

Moos, R. H., \& Moos, B. S. (1976). A typology of family social environments. Family Process, 15(4), 357-371.

Niroula, G. S., \& Thapa, G. B. (2005). Impacts and causes of land fragmentation, and lessons learned from land consolidation in South Asia. Land Use Policy, 22(4), 358-372. https://doi.org/10.1016/j.landusepol.2004.10.001

Rahman, S., \& Rahman, M. (2009). Impact of land fragmentation and resource ownership on productivity and efficiency: The case of rice producers in Bangladesh. Land Use Policy, 26(1), 95-103.

Rodenburg, J., \& Johnson, D. E. (2009). Weed Management in Rice Based Cropping Systems in Africa. Advances in Agronomy, 103, 149-218. https://doi.org/10.1016/S0065-2113(09)03004-1

Sanchez, P. A., \& Leakey, R. R. B. (1997). Land use transformation in Africa: Three imperatives for balancing food security with natural resource conservation, European Journal of Agronomy, 7, 15-23.

Sasson, A. (2012). Food security for Africa: an urgent global challenge. Agriculture \& Food Security, 1(2), 1-16. https://doi.org/10.1186/2048-7010-1-2

Swinnen, J., Colen, L., \& Maertens, M. (2013). Constraints to smallholder participation in high-value agriculture in West Africa, In: Rebuilding West Africa's Food Potential, A. Elbehri (ed.), FAO/IFAD.

Tan, S., Heerink, N., Kuyvenhoven, A., \& Qu, F. (2010). Impact of land fragmentation on rice producers' technical efficiency in South-East China. NJAS - Wageningen Journal of Life Sciences, 57(2), 117-123. https://doi.org/10.1016/j.njas.2010.02.001

Vissoh, P. V., Gbèhounou, G., Ahanchédé, A., Kuyper, T. W., \& Röling, N. G. (2004). Weeds as agricultural constraint to farmers in Benin: results of a diagnostic study. NJAS - Wageningen Journal of Life Sciences, 52(3-4), 305-329. https://doi.org/10.1016/S1573-5214(04)80019-8

WFP (2009). Analyse Globale de la Vulnérabilité et de la Sécurité et de la Nutrition (AGVSAN) au Bénin, 168 p.

\section{Copyrights}

Copyright for this article is retained by the author(s), with first publication rights granted to the journal.

This is an open-access article distributed under the terms and conditions of the Creative Commons Attribution license (http://creativecommons.org/licenses/by/3.0/). 